\title{
Mechanical analysis of transversal iliac fracture stabilization using dynamic compression plate or screws and PMM in polyurethane bone model
}

\author{
[Avaliação mecânica de estabilização de fratura ilíaca transversa com placa de \\ compressão dinâmica ou polimetilmecatrilato associado à parafusos \\ utilizando modelo de osso sintético de poliuretano] \\ T.C. Prada ${ }^{1}$, A.C. Shimano ${ }^{2}$, D. Chung ${ }^{1}$, D.E. Karcher ${ }^{3}$, B.W. Minto ${ }^{2}$ \\ ${ }^{1}$ Aluno de pós-graduação - UNESP- Jaboticabal, SP \\ ${ }^{2}$ Faculdade de Medicina de Ribeirão Preto - USP- Ribeirão Preto, SP \\ ${ }^{3}$ Aluna de graduação - UNESP - Jaboticabal, SP
}

\begin{abstract}
Pelvic fractures correspond to 20 to $30 \%$ of the fractures observed in dogs. Complete fractures, especially with bone axis deviation should be surgically treated. The mechanical study of surgical techniques is of utmost importance to assess the best way of treating these injuries. This study compared, biomechanically, the use of a dynamic compression plate (DCP) and screws (group 1) or screws and polymethylmethacrylate (PMMA) (group 2) to stabilize an iliac fracture using a static test. Sixteen canine synthetic hemi-pelvises (test specimens) with a transverse iliac osteotomy were used. After fixation with implants, a load was applied to the acetabulum until failure. Group 1 maximal compressive load was $133.9 \pm 18.60 \mathrm{~N}$, displacement at yield $21.10 \pm 3.59 \mathrm{~mm}$ and stiffness $125.22 \pm 12.25 \mathrm{~N} / \mathrm{mm}$. Group 2 maximal compressive load was $183.50 \pm 27.38 \mathrm{~N}$, displacement at yield $16.66 \pm 5.42 \mathrm{~mm}$ and stiffness $215.68 \pm 33.34 \mathrm{~N} / \mathrm{mm}$. The stabilization with polymethylmethacrylate was stronger than dynamic compression plate since it resisted a greater load in all test specimens.
\end{abstract}

Keywords: pelvis, stabilization, biomechanical, fracture

\section{RESUMO}

As fraturas da pelve são frequentes em cães, correspondendo a 20-30\% das fraturas encontradas na espécie. A grande maioria delas é tratada cirurgicamente, principalmente aquelas que apresentam desvio ósseo. O estudo mecânico das técnicas cirúrgicas é de extrema importância para avaliação da melhor maneira de tratamento destas lesões. O objetivo deste estudo foi comparar, do ponto de vista biomecânico, a fixação das fraturas do ílio utilizando uma placa de compressão dinâmica ou parafusos associados ao polimetilmetacrilato, por meio de um teste estático. Foram utilizadas 16 hemipelves caninas de origem sintética, nas quais uma osteotomia transversa foi realizada no corpo do ílio. As fixações foram divididas em dois grupos: fixação com placa de compressão dinâmica e parafusos (grupo1) ou parafusos associados ao polimetilmetacrilato (grupo 2). Posteriormente à fixação dos implantes foi aplicada uma carga no acetábulo de cada corpo de prova até a falha. O grupo 2 apresentou força máxima de aplicação de carga a média de $133.9 \pm 18.60 \mathrm{~N}$, deflexão $21.10 \pm 3.59 \mathrm{~mm} e$ rigidez 125.22 $12.25 \mathrm{~N} / \mathrm{mm}$. O grupo 2 apresentou força máxima de aplicação de carga a média de $183.50 \pm 27.38 \mathrm{~N}$, deflexão $16.66 \pm 5.42 \mathrm{~mm}$ e rigidez $215.68 \pm 33.34 \mathrm{~N} / \mathrm{mm}$. A estabilização com o polimetilmetacrilato mostrou ser mais resistente, pois resistiu a uma maior quantidade de carga em relação à placa de compressão dinâmica, em todos os corpos de prova.

Palavras-chave: pelve, estabilização, biomecânica, fratura

Recebido em 8 de maio de 2015

Aceito em 9 de agosto de 2016

E-mail: tiago.prada@yahoo.com.br 


\section{INTRODUCTION}

Pelvic fractures are common in dogs and cats and usually require surgery. Furthermore, the iliac fractures are among the most common (Patrick et al., 2000; Patrick et al., 2002; Breshears et al., 2004). Several techniques are described with good results, although few have been assessed objectively.

Several techniques and implants have been described to treat iliac fractures, each with its peculiarities and different indications. Screws, plates, external fixators, cerclages, and polymethylmethacrylate and screws are the most commonly used orthopedic implants for stabilizing such fractures (DeCamp, 2012).

The pelvis is a thin and flat bone and, therefore, has little bone stock for anchoring the orthopedic implants and thus complications, such as loosening of the screws and fractures in the area, may occur in the postoperative period. Some studies have been conducted to determine the best implants and the best area for their application, including tests with dynamic compression plates and locking plates (Roush e Manley, 1992, DeCamp, 2012). However, screws with polymethylmethacrylate have never been tested on iliac fractures.

Several authors have reported the successful use of polyurethane synthetic bone (test specimens) in mechanical tests, in human medicine, dentistry (O’Neill et al., 2012; Mehmanparast et al., 2014; Rodrigues et al., 2014; Colegatti Filho et al., 2015; Wang et al., 2015) and veterinary medicine (Uhl et al., 2008).

The objective of this study was to evaluate, biomechanically, the use of a dynamic compression plate and screws, and screws and polymethylmethacrylate (PMMA) to stabilize an iliac fracture in synthetic polyurethane models (test specimens).

\section{MATERIALS AND METHODS}

A total of 16 identical size, shape, weight $(105 \mathrm{~g})$, and density $\left(235 \mathrm{~kg} / \mathrm{m}^{3}\right)$ synthetic canine hemi-pelvis models made of polyurethane corresponding to a medium-sized dog (Nacional Ossos ${ }^{\circledR}$ - Jaú - São Paulo, Brasil.), all from the same batch, were used.
The test specimens were divided into two groups $(\mathrm{n}=8)$. Group 1 consisted of the right and group 2, the left hemi-pelvis specimens. Both sides had identical dimensions. The fracture in group 1 was stabilized with a dynamic compression plate (DCP) (Cão Medica ${ }^{\circledR}$ Comércio de Materiais Cirúrgicos Veterinários Ltda. Campinas - São Paulo, Brasil) of $2.7 \mathrm{~mm}$ diameter and $6 \mathrm{~cm}$ length. The 7-hole plate was fastened with 6 cortical screws of $2.7 \mathrm{~mm}^{\mathrm{b}}$ diameter while length varied according to the location used, so that both cortices were inserted. In group 2, fracture was stabilized with polymethylmethacrylate (PMM) (Jet $\AA$ - Artigos Odontológicos Clássico. Campo Limpo Paulista - São Paulo, Brasil) and 6 cortical screws of $2.7 \mathrm{~mm}^{\mathrm{a}}$ diameter while length also varied according to the application site. The screws were fastened in the same region in both groups. All implants were made of $316 \mathrm{~L}$ steel. All screws used to make the specimens were self-tapping. Numbers of screws and insertion technique were based on principles of AO foundation (Johnson et al., 2005).

A transverse osteotomy was performed in each specimen using an oscillating bone saw, just two and a half centimeters cranial to the acetabulum. In group 1, the plate was molded according to the bone anatomy prior to the transverse osteotomy. The fixation plate was first fastened to the fractured caudal fragment with a cortical screw using neutral drilling, followed by fixation to the cranial fragment with a cortical screw using compression drilling. Subsequently, two cortical screws were fastened into each fractured fragment using neutral drilling.

In group 2, after osteotomy, the same bone plate of group 1 was used to mark the drilling holes for the cortical screws. A guide was used to drill and fasten the cortical screws that pierced the cis and trans cortices. The fragments were reduced manually while the previously weighed liquid polymethylmethacrylate (5 grams polymethylmethacrylate polymer to $5 \mathrm{~mL}$ acrylic liquid), standardized amount, was applied manually around the screws. Then, we waited approximately 5 minutes for the polymerization.

The torque applied to fasten the screw was not measured directly and objectively; however, the technician who performed it had been extensively trained during the preparation of the specimens. 
After stabilizing the osteotomy, the specimen was fixed onto the ilium wing, in a polyvinyl chloride (PVC) tube of $2.5 \mathrm{~cm}$ diameter and $3.5 \mathrm{~cm}$ tall, using polymethylmethacrylate bone cement.

The bending test was performed using the universal testing machine EMIC ${ }^{\circledR}$ DL10000 (EMIC Equipamentos e Sistemas de Ensaio São José dos Pinhais - Paraná, Brasil) configured with $50 \mathrm{~N}$ and $20 \mathrm{~N}$, load cell and preload, respectively. The load application speed was
$20 \mathrm{~mm} / \mathrm{min}$. The data were analyzed by the Tesc ${ }^{\circledR}$ software of the equipment.

The load was applied to the acetabulum to mimic the clinical application. To apply the load, we used an apparatus made from the acetabulum specimens utilizing cement measuring approximately two centimeters in diameter (Figure 1). Despite the specimens being made identically we chose this method to standardize the load application.

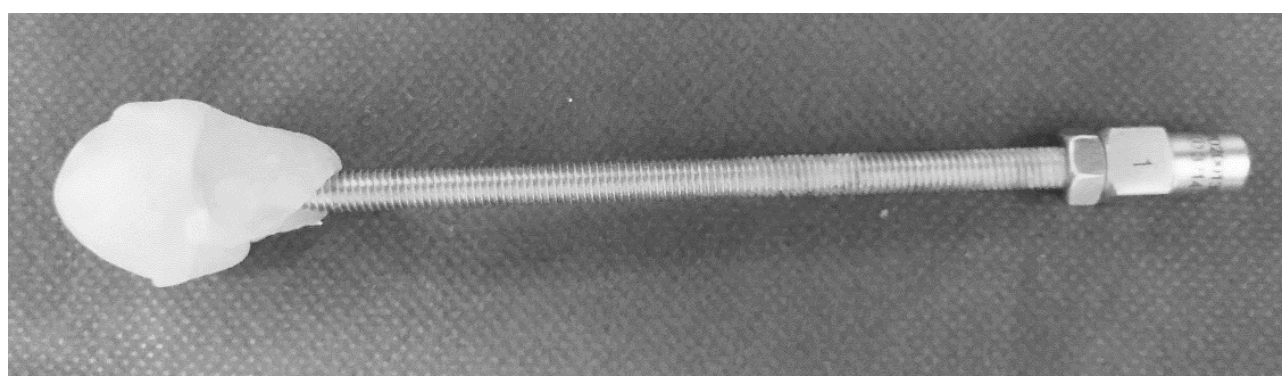

Figure 1. Apparatus used to apply the load on acetabulum.

The specimen was set in an apparatus previously manufactured for this type of analysis, at a $45^{\circ}$ in relation to the load cell to mimic the force applied to the bone physiologically.

All samples underwent the bending test to specimen failure. The application of the load was carried out steadily and continuously, maintained throughout the elastic and plastic phases to material failure, when the test was stopped. The evidence of specimen failure was observed visually and the following complications have been considered: screw loosening, deformation or breakage of the plate and PMM breakage.

The variables were analyzed by repeated measures ANOVA, and when significant differences were observed, the means were compared by Tukey test. Statistical analysis was performed using The SAS Version 6.12 (SAS Institute, Cary, North Carolina) and Statview 5 (SAS Institute 1998) were used.

\section{RESULTS}

All specimens were able to effectively mimic the real bone (canine hemi-pelvis) during fixation of orthopedic implants and realization of biomechanical tests. The use of specimens is advantageous for standardizing the procedures because they have the same weight, shape and dimensions.

In group 1 (DCP), all specimens failed, i.e., the bone fractured adjacent to the screws, especially those adjacent to the fracture site (Figure 2a). In group 2 (PMM), the specimens fractured dorsally to the fracture site $(\mathrm{n}=7)$ (Figure $1 \mathrm{~b})$ while the cement broke up above the first screw adjacent to the fracture site $(n=1)$.

Table 1 shows the results of the mechanical bending tests for specimens of group 1 .

Table 2 shows the results of the bending tests for the specimens of group 2 . 


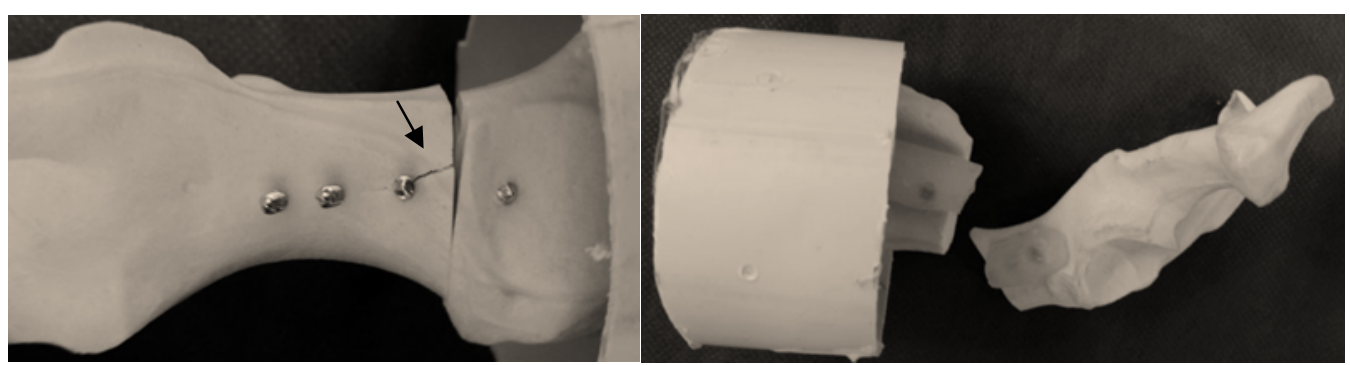

Figure 2. (a) photo of medial view of one specimen in group 1 showing the fracture in the screw region adjacent to the fracture site, in the caudal segment (arrow); (b) Lateral view of one specimen in group 2 showing the transverse fracture of the polymethylmethacrylate.

Table 1. Mean values for maximum force $(\mathrm{N})$, displacement $(\mathrm{mm})$, and stiffness $(\mathrm{N} / \mathrm{mm})$ obtained for the specimens of group 1 stabilized with the dynamic compression plate and screws

\begin{tabular}{cccc}
\hline Specimens & Maximum force $(\mathrm{N})$ & Displacement $(\mathrm{mm})$ & Stiffness $(\mathrm{N} / \mathrm{mm})$ \\
\hline 1 & 128 & 27.42 & 133.1 \\
2 & 159 & 23.92 & 145.6 \\
3 & 130 & 18.31 & 113.8 \\
4 & 137 & 20.65 & 139.4 \\
5 & 129 & 19.20 & 118.3 \\
6 & 162 & 21.66 & 118.2 \\
7 & 110 & 21.96 & 116.3 \\
8 & 116 & 15.64 & 117.1 \\
Media & $133.9 \pm 18.60$ & $21.10 \pm 3.59$ & $125.22 \pm 12.25$ \\
\hline
\end{tabular}

Table 2. Mean values for maximum force $(\mathrm{N})$, displacement $(\mathrm{mm})$, and stiffness $(\mathrm{N} / \mathrm{mm})$ obtained for specimens of Group 2 using PMM and screws

\begin{tabular}{cccc}
\hline Specimens & Maximum force $(\mathrm{N})$ & Displacement $(\mathrm{mm})$ & stiffness $(\mathrm{N} / \mathrm{mm})$ \\
\hline 1 & 170 & 12.05 & 277.0 \\
2 & 163 & 13.72 & 211.3 \\
3 & 193 & 21.56 & 185.9 \\
4 & 233 & 16.36 & 246.8 \\
5 & 178 & 18.42 & 179.3 \\
6 & 208 & 26.98 & 201.8 \\
7 & 177 & 11.53 & 229.0 \\
8 & 145 & 11.53 & 194.4 \\
Media & $183.50 \pm 27.38$ & $16.66 \pm 5.42$ & $215.68 \pm 33.34$ \\
\hline
\end{tabular}

The mean maximum force $(\mathrm{p}<0.0009)$ and stiffness $(\mathrm{p}<0.0001)$ were significantly higher for specimens of group 2 compared to group 1 . On the other hand, mean displacement was not significantly different between the two groups.

\section{DISCUSSION}

The bending tests of iliac fractures stabilized with bone plates and external fixators (Fitzpatrick et al., 2008; Bruce et al., 2014) in cadaveric bones yielded higher values compared to this study.

The natural bone was replaced by polyurethane models to facilitate the standardization of the test specimens thus providing a more homogeneous result. Some authors have reported the use of this material, especially in medicine and dentistry
(O’Neill et al., 2012; Mehmanparast et al., 2014; Rodrigues et al., 2014; Colegatti Filho et al., 2015; Wang et al., 2015) and veterinary (Uhl et al., 2008).

The use of bone plates through the lateral approach is the treatment of choice for stabilizing iliac fractures (Piermattei, 1993; DeCamp, 2012). However, approaches not tested in this study can be considered when treating such fractures (Langley-Hobbs et al., 2009; Krebs et al., 2014). 
The plate and cortical screws technique used on specimens of group 1 was based on description from the literature (DeCamp, 2005). The screws were fastened in the same sites on specimens of groups 1 and 2; however, the plate of group 1 was replaced by PMM application in group 2 according to the authors' previous experience. The implant size was based on the size of the specimens used, while respecting the aforementioned recommendations (Kock, 2005).

The screw and the polymethylmethacrylate association has proven to be a good choice to treat iliac fractures (Burton, 2011), as well as in the treatment of acetabular fractures (Stubbs et al., 1998). The versatility of use has been the special feature reported (Stubbs et al., 1998; Burton, 2011).

The compression of the fracture site through dynamic compression plates avoids the force sharing between the bone and the implant, thus overloading the bone column (Hulse et al., 2005), which may collapse before the implant fails. This technique was used in group 1, and the synthetic bone broke before the implant failed. This technique cannot be performed when the fracture is treated with screws and polymethylmethacrylate association.

The maximum force measured in group 1 varied between $110 \mathrm{~N}$ and $162 \mathrm{~N}$. On the other hand, in group 2 the maximum force ranged from $145 \mathrm{~N}$ to 233N. Fitzpatrick et al. (2008) used dynamic compression plates for stabilizing oblique iliac fractures and reported values ranging from $577 \mathrm{~N}$ to $1467 \mathrm{~N}$. The authors used cadaveric bones and biomechanical test methodology similar to this study. They also tested, using the same methodology, the skeletal external fixation and reported higher values compared to the plate.

On the other hand, Bruce et al. (2014) tested dynamic and blocked compression plates for stabilizing the oblique iliac fractures and have concluded that, biomechanically, there are no significant differences in the maximum force supported by both implants studied. These authors reported maximum values of $936 \mathrm{~N}$ and $1022 \mathrm{~N}$ for dynamic and blocked compression plates, respectively. However, these values are much higher than those found in this study.
The stabilization of acetabular fractures with screw and polymethylmethacrylate has been previously tested only on a biomechanical study by Stubbs et al. (1998). The conclusion of this study was that compared to bone plates, this type of stabilization is easier to perform and ensures the same resistance. Burton (2011) reports that this type of stabilization promotes good clinical and functional recovery of the animal, and the main advantage is versatility.

The stiffness of the implant used in group 2 was significantly higher than group 1 , with the highest values of $277 \mathrm{~N}$ and $145.6 \mathrm{~N} / \mathrm{mm}$, respectively. These results for group 1 are similar to those reported by Bruce et al. (2014) and Fitzpatrick et al. (2008). Furthermore, the external fixators (Fitzpatrick et al., 2008) displayed similar stiffness to the stabilization used in group 2 .

Displacement was not significantly different between the two groups. However, the tests performed by other authors (Stubbs et al., 1998; Fitzpatrick et al., 2008; Bruce et al., 2014) yielded lower results, which can be explained by the use of synthetic bones in this study. The density of polyurethane lower than that of natural bone (O'Neill et al., 2012) and, therefore, the displacement results are lower when animal bones are used.

Clinical failure in the stabilization of the ilium is usually associated with loosening screws of the fracture cranial segment (Breshears et al., 2004; Doornink et al., 2006). After reaching the failure point, the specimens were observed and they all showed a fracture line between the screws of the fracture caudal fragment that resulted in loosening of the screws. Likewise Fitzpatrick et al. (2008) reported the same behavior for all specimens after failure. Unlike the study by Bruce et al. (2014), where the specimens exhibited different behaviors, and the loosening of the screws occurred in the cranial fragment and in some cases there was bending of the plate.

Although group 1 displayed lower values than group 2, the failure in group 1 resulted in breakage of the bone adjacent to the implant while in group 2, the implant broke.

The database consulted by the authors had no biomechanical studies demonstrating the 
application of PMM for stabilizing iliac fractures, except for one clinical trial (Burton, 2011), in which no complications have been reported. After the bending test, all specimens of group 2 displayed a breakdown of the PMM above the fracture site. Likewise, Stubbs et al. (1998) reported the same results for the stabilization of the acetabulum using the same technique. Considering that the major complication of iliac fracture stabilization is the loosening of the screws, the PMM used around the screws worked as a locking system, thus preventing this complication (Burton, 2011).

In clinical practice, the PMM should be used with caution to stabilize iliac fracture due to its proximity with the sciatic nerve, keeping in mind that this compound undergoes an exothermal reaction during polymerization (Burton, 2011). PMM should be applied during the elastic phase and must be irrigated with sterile solution during the heating process. PMM advantages are its versatility and the fact that it can be used in sites where fractured fragments are small.

Among the limitations of the study is the fact that the synthetic bone cannot yield the same results compared to cadaveric bones due to the lower density and lower adhesion of the implants to the specimens. The PMM used on this study was the non-sterilized dental model. Furthermore, this study utilized a transverse osteotomy, and the most common type of fracture in this region is oblique (Vangundy et al., 1988; DeCamp, 2012). A cyclic test was not performed in this study, in order to simulate the stabilization in relation to the dog's movement.

\section{CONCLUSION}

The results show superiority stabilization using polymethylmethacrylate and screws when compared to the dynamic compression plate, thus allowing their clinical use as an alternative to conventional implants.

\section{REFERENCES}

BRESHEARS, L.A.; FITCH, R.B.; WALLACE, L.J. The radiographic evaluation of repaired canine ilial fractures (69 cases). Vet. Comp. Orthop. Traumatol., v.17, p.64-72, 2004.
BRUCE, C.W.; GIBSON, T.W.G.; RUNCIMAN, R.J. A Comparison of conventional compression plates and locking compression plates using cantilever bending in an ilial fracture model. Vet. Comp. Orthop. Traumatol., v.27, p.430-435, 2014.

BURTON, N.J. Composite fixation of comminuted ilial wing fractures in cats: three cases. J. Feline Med. Surg., v.13, p.376-382, 2011.

COLEGATTI FILHO, T.S.; RODRIGUES, D.C.; LAURIA, A. et al. Development plates for stable internal fixation: study of mechanical resistance in simulated fractures of the mandibular condyle. J. Cranio-maxill. Surg., v.43, p.158-161, 2015.

DECAMP, C.E. Fractures of the ilium. In: JOHNSON, A.L.; HOULTON, J.E.F.; VANNINI, R. Ao principles of fracture management in the dog and cat. Switzerland: Thieme, 2005. p.170-177.

DECAMP, C.E. Fractures of the pelvis. In: TOBIAS, K.M.; JOHNSTON, S.A. Veterinary small animal surgery. St. Louis: Elsevier Saunders, 2012. p.801-815.

DOORNINK, M.T.; NIEVES, M.A.; EVANS, R. Evaluation of ilial screw loosening after triple pelvic osteotomy in dogs: 227 cases (19911999). J. Am. Vet. Med. Assoc., v.228, p.535541, 2006.

FITZPATRICK, N.; LEWIS, D.; CROSS, A. A biomechanical comparison of external skeletal fixation and plating for the stabilization of ilial osteotomies in dogs. Vet. Comp. Orthop. Traumatol., v.21, p.349-357, 2008.

HULSE D.; KERIN, S.; MERTENS, D. Fractures of the femoral diaphysis. In: JOHNSON, A.L.; HOULTON, J.E.F.; VANNINI, R. AO principles of fracture management in the dog and cat. Davos: $\mathrm{AO}$ Publishing, 2005. p.286-296.

JOHNSON, A.L.; HOULTON, J.E.F.; VANNINI, R. AO principles of fractures management in dogs and cats. Davos: AO Publishing, 2005. 529p.

KOCK, D. Screws and plates. In: JOHNSON, A.L.; HOULTON, J.E.F.; VANNINI, R. AO principles of fracture management in the dog and cat. Davos: AO Publishing, 2005. P.26-52. 
KREBS, R.C.; ROE, S.C.; DUNCAN, B. et al. Biomechanical evaluation of the influence of an intramedullary pin on the stability of a feline ilial fracture model stabilized with a bone plate. Vet. Surg., v.43, p.114-119, 2014.

LANGLEY-HOBBS, S.J.; MEESON， R.L.; HAMILTON, M.H. et al. Feline ilial fractures: a prospective study of dorsal plating and comparison with lateral plating. Vet. Surg., v.38, p.334-342, 2009.

MEHMANPARAST, H.N.; MAC-THIONG, J.M.; PETIT, Y. Estimation of pedicle screw fixation strength from probe indentation force and screw insertion torque: a biomechanical study on bone surrogates of various densities In: $36^{\text {th }}$ Conference proceedings of Engineering in Medicine and Biology Society, Chicago, p.43504353, 2014.

O'NEILL, F.; CONDON, F.; MCGLOUGHLIN, T. et al. Validity of synthetic bone as a substitute for osteoporotic cadaveric femoral heads in mechanical testing: a biomechanical study. Bone Joint Res., v.1, p.50-55, 2012.

PATRICK F.E.; BOYD J.S.; LI, A.A classification system for small animal pelvic fractures. Clin. Anat., v.13, p.225, 2000.

PATRICK, F.E.; BOYD, J.S.; LI, A. External fixation of pelvic fractures in dogs. Clin. Anat., v. 15, p. $73,2002$.

PIERMATTEI, D.L. Approach to the ilium. In: PIERMATTEI, D.L. An atlas of surgical approaches to the bones and joints of the dog and cat. 3.ed. Philadelphia: Saunders, 1993. [324p.].
RODRIGUES, D.C.; FALCI, S.G.; LAURIA, A. et al. Mechanical and photoelastic analysis of four different fixation methods for mandibular body fractures. J. Craniomax. Surg., v.14, p.344348, 2014.

ROUSH, J.K.; MANLEY, P.A. Mini plate failure after repair of ilial and acetabular fractures in 9 small dogs and 1 cat. J. Am. Vet. Med. Assoc., v.28, p.112-118, 1992.

SAS Institute. Base SAS software, 6.12 ed. Cary, NC: SAS Institute.

STUBBS, W.P.; LEWIS, D.D.; MILLER, G.J. A biomechanical evaluation and assessment of the accuracy of reduction of two methods of acetabular osteotomy fixation in dogs. Vet. Surg., v.27, p.429-437, 1998.

UHL, J.M.; SEGUIN, B.; KAPATKIN, A.S. et al. Mechanical comparison of $3.5 \mathrm{~mm}$ broad dynamic compression plate, broad limitedcontact dynamic compression plate, and narrow locking compression plate systems using interfragmentary gap models. Vet. Surg., v.37, p.663-673, 2008.

VANGUNDY, T.E; HULSE, D.A.; NELSON, J.K. Mechanical Evaluation of two canine iliac fracture fixation systems. Vet. Surg., v.17, p.321327, 1988.

WANG, T.M.; LEE, M.S.; WANG, J.S.; LIN, L.D. The effect of implant design and bone quality on insertion torque, resonance frequency analysis, and insertion energy during implant placement in low or low- to medium-density bone. Int. J. Prostho., v.28, p.40-47, 2015. 